\title{
UPAYA MENINGKATKAN KEMAMPUAN BERBICARA MAHASISWA MENGGUNAKAN MEDIA APLIKASI GOOGLE MEET BERBASIS UNGGAH TUGAS VIDEO DI YOUTUBE PADA MASA PANDEMI COVID-19
}

\author{
Agus Darmuki \\ IKIP PGRI Bojonegoro \\ agus_darmuki@yahoo.co.id
}

\begin{abstract}
This study aims to improve student learning outcomes by using the google meet application media based on uploading video assignments on YouTube. The subjects of this study were 28 students of class I B of the Indonesian Language and Literature Education Study Program, IKIP PGRI Bojonegoro. The object of this research is the students of the PBSI Study Program who take the Speaking Skills course in the first semester. This type of research is a classroom action research consisting of two cycles, each cycle consists of planning, implementing, observing and reflecting. The data collection instruments used observation, documentation, and speaking practice tests uploaded on YouTube. The results showed that there was an increase in the percentage of student completeness in pre-cycle by 43\% (12 students), in the first cycle it was 61\% (17 students), in the second cycle, the percentage of student completeness increased to 89\% (25 students). The conclusion of the research findings is that using the google meet application media based on uploading assignments on YouTube can improve the learning outcomes of students' speaking skills in class I B of the PBSI Study Program, IKIP PGRI Bojonegoro, Academic Year 2020/2021.
\end{abstract}

Keywords: Google Meet, Youtube, Speaking, Covid-19

\begin{abstract}
ABSTRAK
Penelitian ini bertujuan untuk meningkatkan hasil belajar kemampuan berbicara mahasiswa dengan menggunakan media aplikasi google meet berbasis unggah tugas video di youtube. Subjek penelitian ini adalah mahasiswa kelas I B Prodi Pendidikan Bahasa dan Sastra Indonesia IKIP PGRI Bojonegoro yang berjumlah 28 mahasiswa. Objek penelitian ini adalah mahasiswa Prodi PBSI yang mengambil mata kuliah Keterampilan Berbicara pada semester satu. Jenis penelitian ini yaitu penelitian tindakan kelas yang terdiri dari dua siklus, setiap siklus terdiri dari perencanaan, pelaksanaan, observasi dan refleksi. Instrumen pengumpulan data menggunakan observasi, dokumentasi, dan tes praktik berbicara yang diunggah di youtube. Hasil penelitian menunjukkan bahwa terjadi peningkatan prosentase ketuntasan mahasiswa pada prasiklus sebesar 43\% (12 mahasiswa), pada siklus I sebesar 61\% (17 mahasiswa), pada siklus II, prosentase ketuntasan mahasiswa meningkat menjadi 89\% (25 mahasiswa). Kesimpulan temuan penelitian ini bahwa menggunakan media aplikasi google meet berbasis unggah tugas di youtube dapat meningkatkan hasil belajar keterampilan berbicara mahasiswa pada kelas I B Prodi PBSI IKIP PGRI Bojonegoro Tahun Akademik 2020/2021.
\end{abstract}

Kata Kunci: Google Meet, Youtube, Berbicara, Covid-19

Submitted Nov 25, 2020 | Revised Des 13, 2020 | Accepted Des 16, 2020

\section{Pendahuluan}

Pada masa pandemi Covid-19 seperti saat ini, beberapa kampus memilih sistem pembelajaran dengan cara online (daring) atau lebih dikenal dengan istilah Pembelajaran Jarak Jauh (PJJ) (Fuadi dkk., 2020: 193). Pelaksanaan pembelajaran mata kuliah keterampilan berbicara yang biasanya dilakukan secara langsung (tatap muka) sekarang harus dilakukan secara daring. Dosen yang semula mengamati perkembangan kemampuan belajar mahasiswa secara langsung, pada masa pandemi ini kehilangan banyak kesempatan untuk mengamatinya. Pembelajaran lebih banyak dilakukan melalui daring dan evaluasi hasil belajar tidak bisa dilakukan secara langsung atau tatap muka (Anhusadar, 2020: 45).

PJJ yang berlangsung di Prodi Pendidikan Bahasa dan Sastra Indonesia (PBSI)IKIP PGRI Bojonegoro menggunakan beberapa aplikasi, misalnya Zoom, Google Classroom, pemberian materi video yang diunggah di Youtube, Google Meet, dan melalui WA grup. Aplikasi tersebut digunakan dalam belajar 
di masa pandemi covid-19. Kadir (2008: 3) menjelaskan bahwa program aplikasi merupakan program yang siap pakai direka untuk melaksanakan suatu fungsi bagi pengguna atau aplikasi yang lain. Program komputer yang dibuat untuk menolong manusia untuk melaksanakan suatu tugas tertentu. Jadi, dapat disimpulkan bahwa aplikasi adalah perangkat lunak yang diciptakan dan dikembangkan untuk tujuan tertentu pada perangkat komputer, laptop dan smartphone. Dalam pemograman ada aplikasi yang disambungkan dengan internet (Elyas, 2018: 1829). Aplikasi ini harus diinstal dan yang terpenting ada koneksi internet yang dapat menyambungkan. Aplikasi berbasis web merupakan aplikasi yang dapat diakses melalui web browser saat tersambung dengan jaringan internet seperti aplikasi google meet yang digunkan dalam pembelajaran.

Belajar merupakan suatu proses perubahan tingkah laku, dari tidak bisa menjadi bisa, dari tidak tahu menjadi tahu sebagai dampak dari kegiatan pembelajaran (Darmuki dkk., 2017: 45). Pada pembelajaran bahasa terdapat empat keterampilan berbahasa antara lain keterampilan menyimak, keterampilan berbicara, keterampilan membaca, dan keterampilan menulis (Darmuki dkk, 2018: 115). Salah satu jenis keterampilan yang termasuk dalam keterampilan produktif adalah keterampilan berbicara (Darmuki \& Hariyadi, 2019: 256). Darmuki dkk. (2019: 3) juga menjelaskan bahwa keterampilan berbicara adalah salah satu keterampilan berbahasa yang produktif dan ekspresif serta dipergunakan untuk berkomunikasi secara langsung atau secara tatap muka dengan pihak lain untuk tujuan tertentu. Keterampilan berbicara menjadi kebutuhan setiap mahasiswa calon guru untuk berkomunikasi dalam membelajarkan peserta didik di kelas(Darmuki \& Hariyadi, 2019: 62).

Kemampuan berbicara merupakan kemampuan penting yang harus dikuasai mahasiswa terutama mahasiswa di Prodi PBSI sebagai sarana untuk komunikasi, berbagi pengetahuan, ide/gagasan, pikiran, dan pesan/informasi kepada orang lain dengan tujuan tertentu (Darmuki \& Hidayati, 2019: 9). Melalui kegiatan berbicara, para mahasiswa dapat mengungkapkan ide, gagasan, atau perasaan mereka secara langsung kepada orang lain (Darmuki \& Hidayati, 2019: 121). Oleh karena itu, dosen seharusnya benarbenar memperhatikan kemampuan berbicara mahasiswa, termasuk di dalamnya teknik berbicara yang benar.

Pembelajaran berbicara di masa pandemi Covid-19 bagi mahasiswa kelas I B di Prodi PBSI IKIP PGRI Bojonegoro berdasarkan pengamatan awal di lapangan masih belum maksimal, dikarenakan pembelajaran disampaikan dalam bentuk PJJ dengan menggunakan aplikasi yang digunakan google meet. Aplikasi google meet dirasakan belum dimanfaatkan dengan baik untuk pendampingan kegiatan pembelajaran berbicara. Di awal kegiatan pembelajaran, google meet lebih dimanfaatkan untuk kegiatan doa pagi dan menyapa mahasiswa. Padahal kemampuan berbicara merupakan kemampuan dasar yang harus dimiliki setiap mahasiswa sebagai generasi intelektual penerus bangsa yang ditandai intelektualnya dari salah satunya kemampuan berbicara (Darmuki dkk., 2017: 75). Google meet yang tidak maksimal penggunaannya dalam belajar berbicara akan berpengaruh terhadap hasil belajar mahasiswa. Selama ini pengamatan kemampuan berbicara mahasiswa hanya dilakukan melalui penugasan setiap pertemuan perminggu. Penugasan tersebut kurang maksimal untuk mengukur kemampuan berbicara mahasiswa karena masih sebatas teoritis dan belum menyentuh aspek praktik. Sehingga kemampuan mahasiswa kurang berkembang dan masih ada mahasiswa yang berbicaranya belum berani, masih terbata-bata, tidak runtut dan kurang benar.

Berdasarkan hasil praktik awal mahasiwa yang sudah dinilai menunjukkan masih rendahnya kemampuan berbicara mahasiswa. Mahasiswa masih kesulitan dalam berbicara karena belum memahami topik/tema, kesulitan mencari inspirasi, masih gugup/nerves, bahkan ada beberapa mahasiswa yang berbicaranya tidak runtut. Hal ini menunjukkan kemampuan berbicara mereka belum cukup terasah dengan baik dimasa pandemi covid-19 dimana pembelajaran dalam jaringan membuat pembelajaran tidak maksimal. Oleh karena itu, dibutuhkan aplikasi pembelajaran daring dan evaluasi pembelajaran yang dapat membantu mahasiswa tetap maksimal dalam pembelajaran berbicara serta evaluasi yang berbasis performa melalui media yang dekat dengan keseharian mahasiswa (Burke, 2009: 
8). Dalam konteks penelitian ini media aplikasi google meet berbasis unggah tugas di youtube diharapkan dapat meningkatkan pembelajaran berbicara di masa pandemi covid-19 saat ini yang tetap memberikan pembelajaran berbicara secara teori dan evaluasi secara praktik melalui unggah tugas berbicara di youtube.

Google Meet adalah produk dari google yang merupakan layanan komunikasi video yang dikembangkan oleh google. Aplikasi ini adalah salah satu dari 2 aplikasi yang merupakan versi baru dari versi terdahulunya yaitu google hangouts dan google chat . (Lewandowski, 2015: 37). Kelebihan menggunakan aplikasi google meet: (1) Tersedia fitur white board untuk membuat tulisan dan menjelaskan gambar atau angka yang tidak bisa dijelaskan secara lisan; (2) Tersedia gratis, dengan batas waktu penggunaan 1 jam; (3) Mudah menggunakannya, karena hanya membutuhkan akun untuk bisa mendaftar ke aplikasi google meet, (2) Dapat diikuti hingga 100 peserta; (3) Tampilannya menarik dan tampilan layar bisa diatur sesuai keinginan penggunanya; (4) Ada fasilitas berbagi layar untuk menyampaikan dokumen, spreadsheet, atau presentasi. Adapun kelemahan dari aplikasi google meet adalah: (1) Tidak adanya fitur hemat data sehingga membutuhkan data yang banyak jika menggunakan google meet, (2) Belum semua fasilitas gratis. Pengguna harus membeli paket dari google suite sebelum menggunakan fitur yang lebih lengkap; (4) Membutuhkan jaringan internet yang stabil, agar bisa beroprasi sebagaimana mestinya dan bekerja dengan baik. Aplikasi google meet dalam konteks penelitian ini digunakan untuk proses pembelajaran keterampilan berbicara mahasiswa secara daring.

Youtube mempunyai pengertian sebagai situs media digital (video) yang dapat di download, diunggah, serta dibagikan (share) di seluruh penjuru negeri (Baskoro, 2009). Youtube merupakan situs sosial media yang sering dipakai serta fenomenal dikalangan masyarakat (Snelson, 2011; Iwantara dkk., 2014; Rohandi, 2020). Menurut Sianipar (2013) youtube ialah sebuah basis data berisi konten video yang popular di media sosial serta penyedia beragam informasi yang sangat membantu. Youtube mempunyai fungsi untuk mencari suatu informasi video atau melihat video secara langsung (Gomes, 2008: 802). Youtube dirancang sebagai situs berbagi video yang sangat populer terutama dikalangan generasi muda dan bahkan youtube sebagai situs untuk berbagi informasi di era digital saat ini, termasuk salah satunya sebagai media pembelajaran (DeWitt dkk., 2013: 1118). Generasi muda hampir sebagian besar menggunakan youtube dalam kehidupan sehari-hari mereka (Setiadi dkk., 2019: 313). Pemanfaatan media youtube untuk pembelajaran di kalangan mahasiswa menjadi sebuah kebutuhan pembelajaran yang dekat dengan kehidupan mereka (Mujianto, 2019: 136). Penggunaan youtube dalam konteks penelitian ini akan digunakan sebagai sarana unggah tugas keterampilan berbicara.

\section{Metode Penelitian}

Jenis peenelitian ini merupakan jenis penelitian tindakan kelas dengan pendekatan deskriptif kualitatif. Penelitian tindakan kelas ini menggunakan 2 siklus. Setiap siklus yang terdiri dari perencanaan, pelaksanaan, observasi, dan refleksi. Pelaksanaan penelitian ini pada mahasiswa kelas IB Prodi PBSI IKIP PGRI Bojonegoro Tahun Akademik 2020/2021 semester ganjil yang berjumlah 28 mahasiswa dengan rincian terdiri dari 8 laki-laki dan 20 perempuan, usia antara 17-24 Tahun. Sumber data penelitian ini berupa proses pembelajaran mata kuliah keterampilan berbicara dengan satu orang dosen pengampu mata kuliah Keterampilan Berbicara di Prodi PBSI IKIP PGRI Bojonegoro. Objek penelitian ini adalah mahasiswa kelas IB Prodi PBSI yang mengambil mata kuliah Keterampilan Berbicara semester ganjil. Data penelitian ini berupa proses pembelajaran mata kuliah Keterampilan Berbicara di kelas IB Prodi PBSI IKIP PGRI Bojonegoro secara daring menggunakan aplikasi google meet. Instrumen pengumpulan data penelitian ini menggunakan observasi, wawancara, dokumentasi, dan tes praktik berbicara yang diunggah di youtube. KKM yang sudah ditetapkan dalam pembelajaran mata kuliah Keterampilan Berbicara adalah 70.

Instrumen pengumpulan data berupa observasi digunakan untuk mengumpulkan data mengenai proses pembelajaran keterampilan berbicara di kelas IB selama observasi awal, siklus 1 maupun siklus 
2. Observasi menggunakan lembar observasi mahasiswa dan lembar observasi dosen dalam proses pembelajaran secara daring melalui aplikasi googel meet. Wawancara digunakan untuk mengetahui tanggapan dosen mengenai penggunaan metode pembelajaran awal wawancara, selama siklus 1 maupun siklus 2. Wawancara menggunakan panduan wawancara yang sudah disiapkan secara terstruktur. Wawancara dilakukan secara daring melalui apikasi google meet. Instrumen pengumpulan data penelitian berupa dokumentasi, yang digunakan untuk mengumpulkan informasi berupa dokumen terkait dengan penelitian yang dilakukan. Evaluasi pembelajaran keterampilan berbicara menggunakan tes berupa unjuk kerja atau praktik berbicara (Thornbury, 2005: 122) yang diunggah di youtube. Observasi terhadap mahasiswa dilakukan untuk menilai video praktik berbicara mahasiswa yang diunggah di youtube.

\section{Hasil dan Pembahasan}

1. Pra Siklus

Berdasarkan tabel hasil belajar mahasiswa pada Prasiklus, dapat diketahui bahwa 43\% mahasiswa telah lulus KKM, sedangkan sisanya sebesar 57\% masih berada di bawah KKM. Penetapan KKM mata kuliah Keterampilan Berbicara yang sudah ditetapkan dosen adalah 70. Hasil ini menunjukkan bahwa indikator keberhasilan belajar mahasiswa belum terpenuhi.

Tabel 1. Hasil Belajar Berbicara pada Pra-Siklus

\begin{tabular}{lcc}
\hline Indikator Nilai & Jumlah Mahasiswa & Prosentase $(\%)$ \\
\hline$>$ KKM & 12 & $42.86 \%$ \\
$>$ KKM & 16 & $57.14 \%$ \\
Baris 3 & 28 & $100 \%$ \\
\hline
\end{tabular}

Tabel di atas menunjukkan bahwa keterampilan berbicara mahasiswa masih rendah hal itu dapat dilihat tingkat ketuntasan mahasiswa yang memenuhi KKM hanya 12 mahasiswa sedangkan yang belum memenuhi KKM tersebut berjumlah 16 mahasiswa. Selain itu pembelajaran yang sudah dilakukan dosen masih jauh dari yang diharapkan. Berdasarkan hasil wawancara awal juga menunjukkan pembelajaran masih membosankan, mereka belum terbiasa pembelajaran daring. Evaluasi pembelajaran berbicara yang dilakukan dosen juga masih sebatas teoritis.

2. Siklus I

Pada awal pertemuan siklus I, beberapa mahasiswa kurang memperhatikan saat dosen memberikan apersepsi dan menjelaskan tujuan pembelajaran. Ada yang bermain alat tulis, ada yang berbicara dengan anggota keluarganya (mahasiswa belajar dari rumah), dan ada yang sibuk memperhatikan yang lain. Sehingga di awal pembelajaran, banyak mahasiswa yang masih kurang memperhatikan lalu menyebabkan mereka bingung saat praktik berbicara. Dosen juga belum memaksimalkan penggunaan aplikasi google meet berbasis unggah tugas di youtube untuk menayangkan gambar atau contoh video berbicara. Ketika dosen menjelaskan dan, mikrofon mahasiswa dalam keadaan menyala ini sangat mengganggu dengan munculnya dengungan suara.

Pada siklus I ini, peneliti melakukan pendekatan dengan cara mengoreksi unggah tugas video berbicara di youtube mahasiswa setiap kali mereka selesai unggah tugas pertama agar bisa segera diperbaiki. Namun terlihat bahwa beberapa mahasiswa masih bingung saat harus mengunggah tugas video di youtube. Dosen mengarahkan untu melihat tutorial unggah video di youtube dan tutorial edit video di youtube. Ada pula beberapa mahasiswa yang belum lancar berbicara, sehingga masih bertanya kepada teman mahasiswa lain di rumah.

Tabel 2. Peningkatan Hasil Belajar Keterampilan Berbicara pada Pra-Siklus dan Siklus 1

\begin{tabular}{lcc}
\hline Keterangan & Pra-Siklus & Siklus 1 \\
\hline Nilai rata-rata kelas & 71.3 & 74.4 \\
Mahasiswa yang tuntas & 12 & 17 \\
Prosentase ketuntasan kelas (\%) & $42.86 \%$ & $60.71 \%$ \\
\hline
\end{tabular}


Berdasarkan tabel di atas ada peningkatan nilai rata-rata kelas dari prasiklus sebesar 71.3 meningkat pada siklus 1 sebesar 74.4. Mahasiswa yang tuntas juga ada peningkatan dari prasiklus 12 mahasiswa yang tuntas meningkat pada siklus 1 menjadi 17 mahasiswa. Prosentase ketuntasan pada prasiklus sebesar $42.86 \%$ meningkat pada siklus 1 sebesar $60.71 \%$.

3. Siklus II

Semua kelemahan yang muncul pada siklus I menjadi dasar bagi peneliti untuk melakukan perbaikan proses pembelajaran pada siklus II. Pelaksanaan siklus II menunjukkan proses yang lebih baik. Dosen memberikan apersepsi dan juga menayangkan contoh video berbicara di depan umum sebelum memberikan materi secara teoritis. Mahasiswa terlihat lebih antusias untuk mengikuti pembelajaran daring menggunakan aplikasi google meet berbasis unggah tugas di youtube. Mereka juga lebih aktif dan berani bertanya. Dampak positifnya, mereka lebih mampu untuk mengerjakan tugas untuk berbicara melalui media youtube. Penggunaan media youtube untuk praktik berbicara memberikan kesempatan kepada mahasiswa untuk bisa tampil secara maksimal saat membuat video berbicara. Selain itu sebelum membuat video berbicara mereka bisa berlatih berkali-kali untuk berbicara bahkan mereka diberikan kesempatan untuk mengedit video tersebut dengan maksimal sebelum diunggah. Selain belajar keterampilan berbicara penggunaan youtube juga dapat membelajarkan mahasiswa untuk menguasai teknologi misalnya saat mengedit video, bagaimana caranya mengunggah video di youtube, bagaimana cara mengirimkan link video yang sudah diunggah.

Pada pembelajaran siklus II ini ada peningkatan yang tinggi, itu terlihat dari ketika kondisi awal prasiklus mahasiswa yang tuntas hanya $43 \%$ menjadi $89 \%$ ketika pembelajaran siklus II. Selain dari data hasil belajar, hal ini terlihat juga dari observasi melalui aplikasi google meet yang terlihat di kamera. Aktivitas belajar mahasiswa dari siklus I ke siklus II mengalami peningkatan. Mahasiswa terlihat lebih aktif dan antusias mengikuti pembelajaran dengan menggunakan aplikasi google meet berbasis unggah tugas di youtube. Mahasiswa lebih tertarik ketika dosen memulai pembelajaran mulai dari apersepsi, menjelaskan tujuan pembelajaran, dan saat dosen memunculkan share ppt dan contoh video materi berbicara serta memberikan tugas berupa video berbicara dengan tema tertentu dan diunggah di youtube. Berdasarkan hasil wawancara dengan mahasiswa melalui aplikasi google meet bahwa mahasiswa lebih senang belajar menggunakan aplikasi google meet berbasis unggah tugas di youtube karena lebih dekat dengan kehidupan mahasiswa. Hal ini menunjukkan bahwa minat mahasiswa terhadap pembelajaran meningkat. Meningkatnya minat mahasiswa pada saat pembelajaran juga mempengaruhi peningkatan hasil belajar mahasiswa (Iwantara, 2015; Elyas, 2018; Mujiyanto, 2019).

Berdasarkan data pada Prasiklus, Siklus I dan Siklus II dapat disimpulkan bahwa pembelajaran keterampilan berbicara menggunakan aplikasi google meet dapat meningkatkan hasil belajar mata kuliah Keterampilan Berbicara mahasiswa kelas I B di Prodi PBSI IKIP PGRI Bojonegoro. Pembelajaran menggunakan aplikasi google meet berbasis unggah tugas di youtube ini selain meningkatkan hasil belajar kemampuan berbicara mahasiswa juga berdasarkan hasil wawancara dengan mahasiswa dapat meningkatkan minat mahasiswa selama pembelajaran sehingga akhirnya dapat meningkatkan hasil belajar mahasiswa.

Tabel 3. Peningkatan Hasil Belajar Keterampilan Berbicara pada Pra-Siklus, Siklus 1, dan Siklus 2

\begin{tabular}{lccc}
\hline Keterangan & Pra-Siklus & Siklus 1 & Siklus 2 \\
\hline Nilai rata-rata kelas & 71.3 & 74.4 & 80.1 \\
Mahasiswa yang tuntas & 12 & 17 & 25 \\
Prosentase ketuntasan kelas (\%) & $42.86 \%$ & $60.71 \%$ & $82.29 \%$ \\
\hline
\end{tabular}

Berdasarkan tabel di atas bahwa penggunaan aplikasi google meet dapat meningkatkan hasil belajar keterampilan berbicara. Hal ini sesuai dengan pendapat Lewandowski (2015) bahwa penggunaan aplikasi google meet dapat meningkatkan kompetensi berbahasa dan hasil belajar peserta didik. Penggunaan aplikasi google meet berbasis unggah tugas di youtube dapat meningkatkan nilai rata-rata kelas 
dari prasiklus sebesar 71.3 meningkat pada siklus 1 sebesar 74.4 dan meningkat pada siklus 2 sebesar 80.1. Mahasiswa yang tuntas juga ada peningkatan dari prasiklus 12 mahasiswa yang tuntas meningkat pada siklus 1 menjadi 17 mahasiswa selanjutnya pada siklus 2 meningkat menjadi 25 mahasiswa. Prosentase ketuntasan pada prasiklus sebesar 42.86\% meningkat pada siklus 1 sebesar $60.71 \%$ dan meningkat pada siklus 2 sebesar $82.29 \%$. Berdasarkan hasil temuan penelitian di atas penggunaan aplikasi google meet berbasis unggah tugas di youtube dapat meningkatkan kemampuan berbicara mahasiswa di kelas IB Prodi PBSI IKIP PGRI Bojonegoro Tahun Akademik 2020/2021.

\section{Kesimpulan}

Menggunakan aplikasi google meet pada pembelajaran keterampilan berbicara dapat meningkatkan hasil belajar pada mahasiswa kelas I B Prodi PBSI IKIP PGRI Bojonegoro. Selama kegiatan penelitian dan pembelajaran berlangsung, semua berjalan dengan baik. Keterlibatan mahasiswa selama pembelajaran daring menggunakan aplikasi google meet juga sudah berlangsung dengan baik. Peningkatan hasil belajar mahasiswa juga terlihat dari hasil penelitian. Hasil penelitian menunjukkan bahwa pembelajaran keterampilan berbicara menggunakan media aplikasi google meet berbasis unggah tugas di youtube dapat meningkatkan hasil belajar keterampilan berbicara mahasiswa pada kelas I B. Hal ini dibuktikan dengan perbandingan prosentase ketuntasan mahasiswa pada Prasiklus, Siklus I, dan Siklus II. Prosentase ketuntasan mahasiswa pada Prasiklus sebesar 43\% (12 mahasiswa) dan pada Siklus I sebesar 61\% (17 mahasiswa). Pada pelaksanaan Siklus II, prosentase ketuntasan mahasiswa meningkat menjadi 89\% (25 mahasiswa). Saran bagi dosen berdasarkan temuan penelitian di atas dalam pembelajaran keterampilan berbicara dengan aplikasi google meet berbasis unggah tugas video di youtube sebaiknya dosen memperhatikan kesiapan belajar mahasiswa dengan penguasaan kelas yang baik dan pengelolaan waktu yang baik. Dalam pembelajaran keterampilan berbicara menggunakan aplikasi google meet berbasis unggah tugas video di youtube sebaiknya dosen memperhatikan penguasaan aplikasi dengan baik dan cara unggah tugas di youtube sehingga bisa menyampaikan kepada mahasiswa.

\section{Daftar Pustaka}

Anhusadar, L. O. (2020). Persepsi Mahasiswa PIAUD terhadap Kuliah Online di Masa Pandemi. Kindergarten: Journal of Islamic Early Childhood Education, 3(1), 44-58.

Baskoro, A. (2009). Panduan Praktis Searching di Internet. Jakarta : PT Trans Media.

Burke, S.C., Snyder, S., Rager, R.C. (2009). An Assessment of Faculty Usage of Youtube as a Teaching Resource. The Internet Journal of Allied Health Sciences and Practice. Vol. 7(1), 8

Darmuki, A. \& Ahmad Hariyadi. (2019). Eksperimentasi Model Pembelajaran Jucama Ditinjau Dari Gaya Belajar Terhadap Prestasi Belajar Mahasiswa Mata Kuliah Berbicara Di Prodi PBSI IKIP PGRI Bojonegoro. Kredo. 3(1), 62-72.

Darmuki, A. \& Hidayati N.A. (2019). An Investigation of The Cooperative Learning Using Audio Visual Media in Speaking Skill Subject. ICSTI. 121-126.

Darmuki, A. \& Hidayati, N.A. (2019). Peningkatan Kemampuan Berbicara Menggunakan Metode Kooperatif Tipe NHT pada Mahasiswa Tingkat I-A Prodi PBSI IKIP PGRI Bojonegoro Tahun Akademik 2018/2019. Jurnal Pendidikan Edutama. Vol. 6(2), hlm 9-18.

Darmuki, A., Ahmad Hariyadi. (2019). Peningkatan Keterampilan Berbicara Menggunakan Metode Kooperatif Tipe Jigsaw pada Mahasiswa PBSI Tingkat IB IKIP PGRI Bojonegoro Tahun Akademik 2018/2019. Kredo. 2(2), 256-267.

Darmuki, A., Andayani, Joko N., Kundharu S. (2017). Cooperative, Synectics, and CTL Learning Models Toward Speaking Ability Viewd from Students Motivation. Proceeding International Conference on Intellectuals'Global Responsibility (ASSEHR). Vol. 125, 75-79. 
Darmuki, A., Andayani, Joko N., Kundharu S. (2017). Evaluating Information-Processing-Based Learning Cooperative Model on Speaking Skill Course. Journal of Language Teaching and Reasearch. 8(1) pp. 44-51.

Darmuki, A., Andayani, Joko N., Kundharu S. (2018). The Development and Evaluation of Speaking Learning Model by Cooperative Approach. International Journal of Instruction. 11(2), 115-128.

Darmuki, A., Ahmad Hariyadi, Nur Alfin Hidayati. (2019). Developing Beach Ball Group Investigations Cooperative. International Conferences Seword Fresh, 1-7.

DeWitt, D., Alias, N., Siraj, S., Yaakub, M. Y., Ayob, J., \& Ishak, R. (2013). The potential of Youtube for teaching and learning in the performing arts. Procedia -Social and Behavioral Sciences, 103, 1118 -1126 .

Elyas, H. A. (2018). Penggunaan model pembelajaran e learning dalam meningkatkan kualitas pembelajaran. Jurnal Warta. Vol. 56, 1829-7463.

Fuadi, T. M., Musriandi. R., \&Suryani, L., (2020). Covid-19 : Penerapan Pembelajaran Daring Di Perguruan Tinggi. Jurnal Dedikasi Pendidikan, 4(2), 193-200.

Gomes, S. (2008). YouTube in pediatric anesthesia induction. Paediatric Anaesthesia, 18, 801-802.

Iwantara, I.W., Sadia, I.W., dan Suma, I K. (2014). Pengaruh Penggunaan Media Video Youtube dalam Pembelajaran IPA terhadap Motivasi Belajar dan Pemahaman Konsep Siswa. e-Journal Program Pascasarjana Universitas Pendidikan Ganesha, Vol. 4, 1-13.

Lewandowski, M. (2015). Creating Virtual Classrooms (Using Google Hangouts) For Improving Language Competency. Language Issues: The ESOL Journal 26(1): 37-42.

Mujianto, H. (2019). Pemanfaatan Youtube sebagai Media Ajar dalam Meningkatkan Minat dan Motivasi Belajar. Jurnal Komunikasi Hasil Pemikiran dan Penelitian. Vol. 5(1), 135-159.

Setiadi, E. F., Azmi, A., \& Indrawadi, J. (2019). Youtube Sebagai Sumber Belajar Generasi Milenial. Journal of Civic Education, 2(4), 313-323.

Sianipar, A. P. (2013). Pemanfaatan youtube di kalangan mahasiswa. Jurnal Ilmu Komunikasi FLOW, 2(3), 1-10.

Snelson, C. 2011. Youtube across the Disciplines: A Review of Literature. MERLOT Journal of Online Learning and Teaching. Vol. 7(1), 159-169.

Rohandi, Y. (2020). Teaching EFL Students Using Selected Media: Offline Video Taken From YouTube. The journal of Ultimate Research and Trends in Education. Vol 2(1), 29-33.

Thornbury, S. (2005). How to Teach Speaking. Tanpa Kota: Longman. 